\title{
Mediterranean nuts: origins, ancient medicinal benefits and symbolism
}

\author{
Patricia Casas-Agustench ${ }^{1,2}$, Albert Salas-Huetos ${ }^{1}$ and Jordi Salas-Salvadó ${ }^{1,2, *}$ \\ 'Human Nutrition Unit, Faculty of Medicine and Health Sciences, Departament de Bioquímica i Biotecnologia, \\ IISPV, Hospital Universitari Sant Joan de Reus, Universitat Rovira i Virgili, C/Sant Llorenç 21, 43201 Reus, \\ Spain: ${ }^{2}$ CIBER Fisiopatología de la Obesidad y Nutrición (CIBERobn), Instituto de Salud Carlos III (ISCIIII), \\ Madrid, Spain
}

Submitted 13 May 2011: Accepted 7 September 2011

\begin{abstract}
Objective: To consider historical aspects of nuts in relation to origin and distribution, attributed medicinal benefits, symbolism, legends and superstitions.

Design: Review of historical aspects of nuts.

Setting: Mediterranean region.

Subjects: The varieties reviewed include almonds, walnuts, hazelnuts, pine nuts and pistachios.

Results and conclusions: Like other foods, nuts have a wide variety of cultural connections to the areas where they grow and to the people who live there or eat them. History, symbolism and legends reveal the ancient tradition of nuts and how they are related to the lives of our ancestors. Archaeological excavations in eastern Turkey have uncovered the existence of a non-migratory society whose economy centred on harvesting nuts. This shows that nuts have been a staple in the human diet since the beginnings of history. Moreover, since ancient times nuts have been used for their medicinal properties. They also play a role in many old legends and traditions.
\end{abstract}

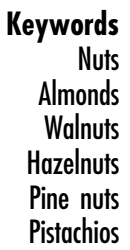

\section{Tree nuts: origin and distribution}

\begin{abstract}
Almonds
Almonds are native to the Mediterranean climate region of the Middle East, Pakistan, Syria and Turkey ${ }^{(1)}$, and other areas in Asia Minor. They were spread by Egyptians, Greeks and Romans in ancient times throughout the Mediterranean and into northern Africa and southern Europe.

The first evidence of the existence of wild almonds comes from Israel during the Pleistocene ( 780000 b.c.e. 'before the common era'). The Acheulian site of Gesher Benot Ya'aqov (Israel) has revealed a unique association of edible nuts with pitted hammers and anvils, which indicates a nut-cracking activity and supports the hypothesis that the pitted stones served as nut-cracking tools ${ }^{(2)}$.

Domesticated almonds appear in the Early Bronze Age (3000-2000 b.c.e.) in the Near East, or possibly a little earlier at the dawn of agriculture. A well-known archaeological example of the almond is the fruit found in Tutankhamun's tomb in Egypt (c. 1325 b.c.e.) and at Deir el-Medina ${ }^{(3)}$, which was probably imported from the Levant $^{(4)}$. Almonds have also been found at the Neolithic level under the palace of Knossos, and in Bronze Age storerooms at Hagia Triada, both on Crete.
\end{abstract}

Around 500-600 c.e. ('of the common era'), Arabs conquered North Africa and brought almonds into Tunisia and Morocco, and eventually into the Iberian Peninsula across the Strait of Gibraltar ${ }^{(5)}$. In the culture of Al-Andalus, almonds were used in many recipes ${ }^{(6)}$.

In the mid-1700s, Spanish Franciscan Friars started to cultivate almonds in their missions along the Royal Road from San Diego to Sonoma. Because of the climatic conditions, almonds were soon grown around the Sacramento area and San Joaquín in the Central Valley. California is currently the leading producer of almonds worldwide $^{(7)}$.

\section{Walnuts}

Walnuts (Juglans regia) are also considered to be one of the oldest tree foods known to man. Historical references date back to Persia in 7000 b.c.e., but they were originally found throughout southeastern Europe and all the way to the Himalayas ${ }^{(8)}$.

The oldest archaeological site where walnuts have been unearthed is in the Shanidar caves in northern Iraq. After this find, at a considerable distance from Persia, evidence of walnuts was discovered in a Mesolithic dunghill in Switzerland ${ }^{(8)}$. 
The Americans, however, had their own native walnuts: the eastern black walnut (J. nigra). Archaeological findings also indicate that native Americans had been eating black walnuts since at least 2000 b.c.e. ${ }^{(9)}$. Of all the walnuts, the Persian or English walnut (J. regia) was the most common, probably the tastiest and certainly the most important $^{(10)}$.

In ancient Persia, only royalty ate walnuts, and they came to be known as Royal Walnuts. Around 2000 b.c.e. in Mesopotamia, the Chaldeans left inscriptions on clay tablets revealing the existence of walnut groves within the famed Hanging Gardens of Babylon. Evidence of walnut consumption dating from the same era can also be found on carved stelae containing the 'Code of Hammurabi', in the section on laws governing food ${ }^{(11)}$.

The first people to cultivate walnuts were the ancient Greeks, who used them not only for food, but also as medicine and dyes for hair, wool and cloth. The Romans, imitators of the Greeks, discovered their merits and were willing to pay dearly for the luxury of serving them along with fruits for dessert. In the ruins of Pompeii, whole, unshelled walnuts were among the foods on the table at the Temple of Isis on that fateful day of 24 August, 79 c.e. when Mount Vesuvius erupted. Although some reports are just myths, walnuts are mentioned in the principal Roman treatises on agriculture: 'De Re Rustica Varro', 'De Re Rustica Columella' and 'Naturalis Historia'(12).

Although there are no written records of the arrival of walnuts in Kashmir, they were an established presence and may have journeyed from there to China during the Han dynasty $^{(8)}$, sometime between 206 b.c.e and 220 c.e.

Although walnuts are often referred to as English walnuts, they did not become popular in England until after World War I when they became a commercial enterprise $^{(8)}$. They acquired this name because they were frequently imported by English ships. The species was taken to the New World by English settlers and to California by missionaries. Nowadays, California is also the largest producer of walnuts ${ }^{(7)}$.

\section{Hazelnuts}

Hazelnuts or filberts come from a number of similar trees of the genus Corylus that are native to Europe, Asia and continental America. The hazel grew wild, forming part of the subsoil of deciduous forests from the most recent glacial period, between around 18000 and 17000 b.c.e. ${ }^{(13)}$. Hazelnuts have been cultivated in China for more than 5000 years $^{(14)}$.

In 1995, archaeologists found evidence of large-scale Mesolithic nut processing on the Hebridean island of Colonsay. Carbon dating shows that the finds date back 9000 years. Hundreds of thousands of burnt hazelnut shells were found in a shallow pit or midden at Staosnaig, on the east coast of this small island. The nuts had been harvested in a single year and pollen analysis suggests that the hazel trees were all cut down at the same time.
The scale and location of the activity is unusual, suggesting that the island community was trading processed hazelnuts with other island and mainland communities ${ }^{(15)}$. On a smaller scale than Staosnaig, there are similar hazelnut middens at Kinloch and Papadil on Rhum ${ }^{(14)}$.

Hazelnuts were also used extensively in the Roman Empire. Carbonised hazelnuts have been recovered from sites destroyed by Mount Vesuvius and provide valuable historical evidence that hazelnuts were used by the ancient Campanians of the first century c.e. ${ }^{(16)}$. For example, in the garden of the House of the Ship Europa at Pompeii, two pieces of carbonised hazelnut shell were found in $1972^{(16)}$. Moreover, carbonised fragments of one of the stakes used to prop up the limbs of a large tree in the garden in the House of Julius Polybius were identified as hazelnut ${ }^{(16)}$.

The leading producer of hazelnuts today is Turkey ${ }^{(17)}$.

\section{Pine nuts}

Pine nuts are the seeds of the pine tree Pinus pinea, which belongs to the Pinaceae family. Some authors maintain that the species is native to the entire Mediterranean basin, whereas others limit its natural range exclusively to the eastern Mediterranean and Asia Minor ${ }^{(18)}$.

Remains of pine nuts from the Mesolithic period have been found in various caves, such as those in Nerja (Málaga) and Lattes in southern France, which show the presence of the pine tree and the use of pine nuts, as well as other nuts, in the diet of human groups ${ }^{(19)}$.

The Hebrew prophet Hosea (ca. 734-732 b.c.e.), who lived in the Northern Kingdom (ancient Israel), referred to pine nuts in the Old Testament (14:8). The ancient Greeks and Romans appreciated the taste of pine nuts. Archaeologists have found pine nuts among household foodstuffs in the ruins of Pompeii (79 c.e.). The Roman legions carried pine nuts among their provisions, and pine-nut shells have been uncovered in refuse dumps of Roman encampments in Britain from the middle of the first century ${ }^{(20)}$.

The current world leader in pine nut production is Spain $^{(7)}$.

\section{Pistachios}

According to Vavilov ${ }^{(21)}$, a prominent Russian and Soviet botanist and geneticist, Pistachios originally came from: (i) central Asia, including northeast India, Afghanistan, Tajikistan and Uzbekistan; and (ii) the near-east, which covers Asia Minor, Caucasus, Iran and the mountain region of Turkmenistan. The presence of pistachio nuts in archaeological excavations provides evidence that the pistachio has long been associated with human activities, and was used as fuel. Pistachio (Pistacia vera L.) cultivation probably began in areas near to which the pistachio grew wild. Remains of pistachio nuts dating from the sixth millennium b.c.e. have been found in Afghani$\operatorname{stan}^{(22)}$ and southeastern $\operatorname{Iran}^{(23)}$. Pistachio cultivation was widespread in the ancient Persian Empire, from where it gradually expanded westward. In Assyria, 
around the tenth century b.c.e., the Queen of Sheba monopolised the limited crop of nuts for her exclusive use $^{(24)}$. Pistachio nuts are mentioned in the Bible (Genesis 43:11) as precious gifts carried from Canaan to Egypt by the sons of Jacob. Pistachios were used as a source of energy in ancient Greece. Amphoras discovered in 2004 on the Greek Aegean Island of Chios reveal the presence of DNA from Pistacia vera and Pistacia lentiscus, suggesting that nuts were traded there around the fourth century b.c.e. ${ }^{(25)}$. In the first century b.c.e., Poseidonius found pistachios cultivated in Syria, which led Greek and Roman writers to erroneously consider Syria as the origin of the pistachio ${ }^{(26)}$. In his Natural History, the Roman author and naturalist Pliny (23 c.e.-25 August, 79 c.e.) says that pistachios were introduced into Italy from Syria by Lucius Vitellius ( 5 b.c.e-51 c.e), the Roman consul of the province at the end of the reign of the emperor Tiberius ${ }^{(27)}$.

From Italy, pistachios were introduced by Flaccus Pompeius into Spain ${ }^{(28)}$ and other Mediterranean regions in southern Europe and North Africa ${ }^{(29)}$.

Pistachio cultivation also spread to China around the tenth century, and more recently to Australia, New Mexico and California. Iran and the USA are today the most important producers ${ }^{(7)}$.

\section{Ancient medicinal benefits of tree nuts}

\section{Almonds}

The Greek physician Hippocrates (ca. 460-370 b.c.e.), considered the "father of medicine, ${ }^{,(30)}$, was the author of the Corpus Hippocraticum, a collection of medical works in which the medicinal effects attributed to almonds are first mentioned. He records that Almonds are burning but nutritious; burning because they are oily and nutritious because they are fleshy ${ }^{\text {,(31) }}$. In the Greek system of humoural physiology, almonds would have been categorised as a hot and dry food: that is to say, one that stimulates choler in the body. Logically, as a medicine in this allopathic system, in which ailments are cured by the administration of substances with opposite qualities, almonds would be ideal for treating colds and other phlegmatic disorders.

The ancients also attributed other wonderful virtues to almonds, such as its supposed ability to prevent intoxication. Almonds were thought to prevent inebriation if consumed before drinking began. The Greek historian Plutarch (c. 46-120 c.e.) mentions a great wine drinker who ate five or six bitter almonds and did not fall victim to intoxication (Plutarch, Mor. 624 c.). The same property is referred to by Dioscorides (40-90 c.e.), a Greek physician (Diosc. i.123,2), and Pliny (Plin xxxiii.145), who even managed to agree on the number of almonds that should be consumed.

Raw or toasted almonds were consumed extensively in Rome. Pliny also gives many medical uses for bitter almonds: 'they provoke sleep and sharpen the appetite, act as a diuretic and emmenagogue. They are also used topically for head-ache, when there is fever more particularly. (...) Used in combination with amylum and mint, they arrest haemorrhage. They are useful, also, for lethargy and epilepsy, and the head is anointed with them for the cure of epinyctis. In combination with wine, they heal putrid ulcers of an inveterate nature, and, with honey, bites inflicted by dogs. They are employed, also, for the cure of scaly eruptions of the face; the parts affected being fomented first'. Pliny only says of sweet almonds, 'their remedial properties are not so extensive; still however, they are of a purgative nature, and are diuretic. Eaten fresh they are difficult to digest ${ }^{\text {(12) }}$.

\section{Walnuts}

This fruit was considered astringent ${ }^{(32)}$, stomachic and suitable to facilitate digestion ${ }^{(33)}$. Heraclides of Tarentun (c. second century b.c.e.), a Greek physician, suggested they were a stimulant to the appetite, and advised that they be eaten at the beginning of a meal ${ }^{(28)}$.

When Pompey (106-48 b.c.e.) had made himself master of the palace of Mithridates, he searched everywhere for the recipe for the famous antidote against poison used by the previous king. At length it was found, and it was very simple: 'Take two dried walnuts, two figs, and twenty leaves of rue; pound them all together, with the addition of a grain of salt; if a person takes this mixture fasting, he will be proof against all poisons for that day' (Plin. xviii. 4).

It is said that, if chewed by a fasting man and applied to a wound, walnut kernels can instantaneously cure bites inflicted by a mad $\operatorname{dog}^{(12)}$.

An infusion of powdered walnut leaves (supposed to have an astringent quality) used to be applied both internally and externally to treat swollen glands, shingles and sores. Walnut oil was prescribed for colic and to soothe the intestines. The juice of green walnut husks, diluted in warm water, was recommended as a mouthwash and to stop diarrhoea. A green walnut, boiled in sugar, was said to relieve constipation. Powdered walnut bark was prescribed to treat ringworm ${ }^{(10)}$.

Until the end of the eighteenth century, walnut milk was considered a nourishing substitute for dairy milk in European households. The Chinese, too, have an ancient custom of making walnut milk, which was thought to be a strength-building food and to possess medical properties ${ }^{(10)}$.

\section{Hazelnuts}

In ancient times, hazelnuts were used as a medicine and tonic. Greek doctors thought they were moderately nutritional and, if eaten raw, they believed they were difficult to digest and so recommended that they be toasted $^{(34)}$. They also believed that consuming too many led to dizziness and headaches. In the first century c.e., the Greek physician Dioscorides emphasised the properties of hazelnuts as a medium to cure colds and grow hair ${ }^{(35)}$. 
In the Middle Ages, both fresh fruit and nuts were consumed very little. Because of the influence of Galen's doctrines, they were considered to be a poor foodstuff and were often seen as the cause of illnesses. In his book Regimen, Arnau de Vilanova (1235-1311 c.e.), an alchemist, astrologer and physician of Catalan origin, tells us that, 'Hazelnuts, due to their nature, give some comfort to the liver, but harm the stomach and the head ${ }^{\text {(36) }}$. Hazelnuts were only used as thickeners, and rarely as ingredients of a dish. They were eaten alone, and with other nuts, but were not seen as worthy of mention in cooking documents or agricultural treatises.

\section{Pine nuts}

Pine nuts were used for medical purposes in the Egyptian culture. In the book The Physicians of Pharaonic Egypt, pine nuts are mentioned as one of the products that the ancient Egyptians used to cure illnesses ${ }^{(37)}$. Both Galen of Pergamum (129-199/217 c.e.), a Roman physician, and Dioscorides believed their properties counteracted cough and chest pain. Galen thought they had clearing properties, and recommended them for patients with expectorant chests and lungs ${ }^{(38)}$. In his book De Materia Médica, Dioscorides says that pine nuts are astringent, have some energetic value and relieve cough and chest infections, either on their own or after being mixed with honey ${ }^{(39)}$.

Pine nuts were used in the Al-Andalus culture as food, and also as a drug. Abū'Alī al-Husayn ibn Sina ${ }^{(40)}$, the doctor, philosopher, mathematician and astronomer born in Persia (980-1037 c.e.), wrote in his most famous work the Kitāb al-qānūn (Canon of Medicine) ${ }^{(40)}$, 'Pine nuts are useful against rotten fluid in the lungs, bleeding, and chronic cough, particularly with boiled fresh grape juice. If you boil them in a sweet wine, they are very good for cleansing lungs of pus. They also give energy and increase sexual appetite and the amount of semen. If pine nuts are eaten together with honey, they cleanse the kidneys and bladder and also protect the bladder from stones and ulcers'. Averroes (1126-1198 c.e.), a renowned Andalusí jurist, philosopher and scholar, also believed that pine nuts, like onions and chickpeas, increased the amount of semen and recommended using their oil as a remedy for stroke and weakness ${ }^{(41)}$.

\section{Pistachios}

Pistachios were known to the Assyrians and the Greeks as a medicinal drug, a potent aphrodisiac and an antidote against bites by poisonous animals. Galen doubted whether pistachio nuts were good for the stomach (Plin. xvii. 5, 8). Avicenna (980-1037 c.e.), a polymath of Persian origin and the foremost physician and philosopher of his time, proved the contrary (Varro. i. 13, 38; Columell. ii. 5, 6, 9), and several centuries before him, the Roman epicures had courageously demonstrated that this fruit never does any harm, whether raw or roasted, alone or accompanied with garum and salt.
In his Canon of Medicine, Avicenna, considered the greatest doctor and scientist of the Islamic Middle East, prescribed pistachios for liver disease and described them as an aphrodisiac. As they are rich in oil, they were used both as food and medicine in Al-Andalus. Averroes says, it is hot and dry, with great warmth. Its oil is a balanced cure, strengthening the stomach and the liver due to its nature as a whole. In general, it is one of the medicines considered to be of great usefulness, ${ }^{,(41)}$. This belief was passed on to medieval Christian doctors. Arnau de Vilanova states that pistachios are good for liver colds (liver cold) and they damage the stomach and harm the head to a lesser extent than other nuts ${ }^{(36)}$.

Pistachios have also been reported as a remedy for sclerosis of the liver, abdominal ailments, abscesses, bruises and sores, chest ailments, circulation problems and other problems ${ }^{(1)}$.

\section{Symbolism, legends and superstitions}

\section{Almonds}

In the ancient religion of Cybele, the goddess of Mother Earth, life, death and resurrection was worshipped in Anatolia since Neolithic times, and the almond was considered to be the goddess' vulva, from which life emerged. The almond is the first tree to flower in spring and therefore a sign of rebirth. It is the symbol of Attis, who was born of a virgin, and was conceived from an almond ${ }^{(42)}$. This legend is a possible explanation for the relationship in the Bible between the almond and the Virgin Mary. Christian symbolism often uses almond branches as a symbol of the virgin birth of Jesus. In the Bible, the almond is mentioned ten times, beginning with the Book of Genesis 43:11, in which it is described as 'among the best of fruits'.

Almonds have symbolised good luck for many centuries in southern Europe; traditionally, candied almond nuts are given away at weddings in Greece as tokens of long life and happiness. In Spain, glistening, ceremonial 'Jordan' almonds from Malaga are usually sugar coated. 'Jordan' refers to a renowned Spanish almond variety, the name of which is probably a corruption of the French word for garden $(\text { jardin })^{(10)}$.

\section{Walnuts}

The scientific name 'Juglans' means 'Jupiter's nut' and 'regia' means 'royal' ${ }^{(8)}$. An old story recounts that in ancient days when men lived upon acorns, the gods lived upon walnuts. This shows that walnuts were highly valued far back in history ${ }^{(43)}$.

According to some authors the walnut originated when Bacchus, the Greek god of wine and ecstasy, fell in love with Carya, the youngest of the three daughters of Dion, King of Laconia ${ }^{(44)}$. When the jealous elder sisters endeavoured to prevent the two lovers from meeting, Bacchus turned them into stone and, for reasons clear only to a god, transformed his beloved into a walnut tree. 
Greeks and Romans considered walnuts a symbol of fertility ${ }^{(10)}$. After the wedding feast the bridegroom strewed in the nuptial chamber, at night, several baskets of walnuts, which children hastened to pick up ${ }^{(45)}$. This was, as the Romans said, a kind of offering to Jupiter, and thus he was entreated to grant his supreme patronage to the husband, and to adorn the wife with the virtues of Juno (Juvenal. Sat. xv. 10). The god could not have failed to smile at this part of the request of blind mortals, and it is asserted that, at times, he did not deign to grant it.

The walnut tree also holds a few dark superstitions. In seventeenth-century Italy there was a walnut tree, the Tree of Benevento, that was believed to be the place where witches gathered. According to legend, the Bishop removed the tree, roots and all, but another witch-haunted tree grew where the original had stood ${ }^{(8)}$.

Superstitions and fears also surrounded the shade of the walnut tree. A passage in Pliny's writings states that the shadow of the walnut tree dulls the brain. He also considered the walnut tree a nuisance wherever it was planted and that nothing should be grown near it, because it contains evil or poison ${ }^{(8)}$.

\section{Hazelnuts}

In many texts hazel and rowan trees, which are not always clearly distinguished lexicographically, are considered to be magical. Druids used hazels in their spells. In Celtic customs, hazels were linked to magical practices. In medieval times, they were attributed with divinatory properties. Warlocks, gold prospectors and water diviners used hazel branches for their practices. In Normandy, cows were beaten three times to give milk. The proceedings of a trial for witchcraft in 1596, in Hesse, contains the following quote: 'If the witch had hit the cow with the branch of the devil, that cow gave milk all the year'. Hazel is therefore sometimes the devil tree ${ }^{(46)}$. However, it is also a symbol of patience and perseverance in the development of mystical experience ${ }^{(46)}$ and in many traditions a symbol of procreation and fertility. For example, in Norse mythology, Iðunn, goddess of life and fertility, is released by Loki, in the form of a falcon, who turns her into a hazelnut to take her back to Asgard ${ }^{(47)}$.

The tree was also the symbol of marriage, wealth and family happiness. In Hanover, Germany, crowds shouted 'Hazelnuts, hazelnuts!' at the groom, and $3 \mathrm{~d}$ after the wedding the bride handed out hazelnuts to symbolise that the marriage had been consummated ${ }^{(46,48)}$. In Russia, during wedding receptions, the mother-in-law threw hazelnuts and oats at the son-in-law, while in Ciutadella (Menorca, Balearic Islands) young men threw hazelnut shells at marriageable girls during the 'Sant Joan' festivities ${ }^{(42)}$.

\section{Pistachios}

Legend has it that the Queen of Sheba decreed pistachios to be an exclusively royal food, going so far as to forbid commoners from growing the nut for personal use $\mathrm{u}^{(24)}$.
They were a symbol of happiness ${ }^{(46)}$. Nebuchadnezzar, the ancient king of Babylon, had pistachio trees planted in his fabled hanging gardens. In the first century c.e., the Emperor Vitellius debuted this prized nut in his capital city of Rome. According to Muslim legend, the pistachio nut was one of the foods brought to earth by Adam ${ }^{(43)}$.

In short, nuts have cultural values that go beyond nutrition and cuisine.

\section{Acknowledgements}

The present study was funded by the Ministry of Education and Science (CICYTAGL2005-03605) and the Ministry of Health (Instituto de Salud Carlos III, RTIC RD06/0045). CIBERobn is an initiative of the Instituto de Salud Carlos III, Spain. J.S.-S. received research funding from the International Nut Council, Reus, Spain. He is an unpaid member of the Scientific Advisory Board of the International Nut and Dried Food Foundation. The authors have no other conflict of interest to declare. P.C.-A. and J.S.-S. contributed to drafting and revising the manuscript with intellectual and scientific input; A.S.-H. contributed to drafting the manuscript. All authors have seen and approved the content and contributed significantly to the work.

\section{References}

1. Rieger M (2006) Introduction to Fruit Crops. New York: Food Products Press.

2. Goren-Inbar N, Sharon G, Melamed Y et al. (2002) Nuts, nut cracking, and pitted stones at Gesher Benot Ya'aqov. Proc Natl Acad Sci 99, 2455-2460.

3. Wilkins JM \& Hill S (2006) Food in the Ancient World (Ancient Cultures). Maldem: Blackwell Publishing.

4. Zohary D \& Hopf M (2000) Domestication of Plants in the Old World: The Origin and Spread of Cultivated Plants in West Asia, Europe, and the Nile Valley. Oxford: Oxford University Press.

5. Kester DE \& Gradziel TM (1996) Almonds. In Fruit Breeding, vol. 3, Nuts, pp. 1-98 [J Janick and JN Moore, editors]. New York: John Wiley \& Sons Inc.

6. Benavides Barajas L (1992) Al-Andalus, la cocina y su bistoria. Motril: Dulcinea.

7. Salas-Salvadó J, Ros E \& Sabaté J (2005) Frutos secos, salud $y$ culturas mediterráneas. Barcelona: Editorial Glosa.

8. Malhotra SP (2008) World Edible Nuts Economy. New Delhi: Concept Publishing Company.

9. Chiffolo AF \& Hesse RW (2006) Cooking with the Bible. Biblical Food, Feasts and Lore. Westport: Greenwood Press.

10. Rossengarden F (1984) The Book of Edible Nuts. New York: Walker and Company.

11. Draine B \& Hiden M (1998) The Walnut Cookbook. Berkeley, CA: Ten Speed Press.

12. Pliny the Elder, John B \& Riley HT (1855) The Natural History [GR Crane, editor]. London: Taylor and Francis.

13. Thompson MM, Lagerstedt HB \& Mehlenbacher SA (1996) Hazelnuts. In Fruit Breeding, vol. 3, pp. 125-184 [J Janick and J Moore, editors]. New York: John Wiley \& Sons.

14. Hummer K (1995) The mystical powers and culinary delights of the hazelnut: a globally important Mediterranean crop. Diversity 11, 130. 
15. Mithen S, Nyree F, Carruthers W et al. (2001) Plant use in the Mesolithic: evidence from Staosnaig, Isle of Colonsay, Scotland. J Archaeol Sci 28, 223-234.

16. Jashemski WF \& Meyer FG (2002) The Natural History of Pompeii. Cambridge: Cambridge University Press.

17. International Nut and Dried Fruit Foundation (2010) Nuts and Dried Fruits Global Statistical Review 2004-2009. Reus: INC.

18. Martínez F \& Montero G (2004) The Pinus pinea L. woodlands along the coast of South-western Spain: data for a new geobotanical interpretation. Plant Ecol 175, 1-18.

19. Gil L (1999) Las Transformaciones históricas del paisaje: la permanencia y la extinción local del pino piñonero. Los montes y su historia: Una perspectiva política, económica y social. Huelva: Universidad de Huelva.

20. Whited TL, Engels JI, Hoffmann RC et al. (2005) Northern Europe: An Environmental History. Santa Barbara: ABCCLIO Inc.

21. Vavilov VL (1951) The origin, variation, immunity and cultivated plants. Chronica Botanica 13, 1-364.

22. Wilcox G (1991) Carbonized plant remains from Shortughai, Afghanistan. In New Light on Early Farming: Recent Developments in Palaeoethnobotany, pp. 139-153 [JM Renfrew, editor]. Edinburgh: Edinburgh University Press.

23. Prickett M (1986) Settlement during the early periods. In Excavations at Tepe Yahya, Iran 1997-1975: The Early Periods, pp. 215-246 [CC Lamberg-Karlovsky, editor]. Cambridge: Harvard University Press.

24. Whitehouse WE (1957) The pistachio nut: a new crop for the western United States. Econ Bot 11, 281-321.

25. Hansson MC \& Foley BP (2008) Ancient DNA fragments inside Classical Greek amphoras reveal cargo of 2400-yearold shipwreck. J Archaeol Sci 35, 1169-1176.

26. Joret C (1976) Les plantes dans l'antiquité et au moyen âge; histoire, usages et symbolisme. Geneve: Slatkine Reprints (Reprinted from the book first published in 1897-1904).

27. Bonifacio P (1942) Il pistaccio; coltivacione, commercio, uso. Rome: Ramo editoriale degri agricoltori.

28. Strutt J (1775) Manners and Customs of the Inhabitants of England, vol. 1, pp. 32. London: Menthuen and Co.

29. Lemaistre J (1959) Le pistachier: étude bibliographique. Fruits 14, 57-77.

30. Grammaticos PC \& Diamantis A (2008) Useful known and unknown views of the father of modern medicine, Hippocrates and his teacher Democritus. Hell J Nucl Med 11, $2-4$.
31. Hippocrates (1967) The Sacred Disease. Jones WHS, translation of Hippocrates works, vol. 2, pp. 37-41. Cambridge, MA: Harvard University Press.

32. Varro. De Re Rustic.; Plin. xviii. 7; Plutarch. I Caesar.

33. Plutarch. De Isid.; Tibull. lib. i. eleg. vii. 29.

34. Diocles, fr. 126 Wellman, Filotimo, Dífilo y Mnesíteo, fr. 30 Bertier, in Ath. II 53e-f and 54b.

35. Lev E \& Amar Z (2006) Reconstruction of the inventory of materia medica used by members of the Jewish community of medieval Cairo according to prescriptions found in the Taylor-Schechter Genizah collection, Cambridge. J Ethnopharmacol 108, 428-444.

36. Cruz J (1997) Dietética medieval: Apéndice con la versión castellana del Régimen de salud de Arnaldo de Vilanova. Huesca: La Val de Onsera.

37. Ghalioungui P (1983) La Médecine des pharaons: Magie et science médicale dans l'Egypte ancienne. Les Enigmes de l'univers. Paris: Robert Laffont.

38. Wafid Ibn (1995) Kitab al-adwiya al-mufrada (Libro de los medicamentos simples) [LFA de Cárcer, edition and translation]. Madrid: Consejo Superior de Investigaciones Científicas y Agencia Española de Cooperación Internacional.

39. Pedacio DA (1991) Acerca de la materia medicinal y de los venenos mortífero [Ade Laguna, editor]. Madrid: Comunidad de Madrid, Secretaría General Técnica.

40. Avicenna (1490) Canon Medicinae [G Cremonensi and A de Villa, editors]. Venetiis: Bonetus Locatellus.

41. Averroes (2003) El libro de las generalidades de la medicina [MCV de Benito and CA Morales, editors]. Madrid: Editorial Trotta.

42. Chevalier J \& Gheerbrant A (1999) Diccionario de los simbolos, 6th ed. Barcelona: Herder.

43. Elzebroek ATG \& Wind K (2008) Guide to Cultivated Plants. Winslow: CAB International.

44. Leslie C \& McGranahan GH (1998) The origin of the walnut. In Walnut Orchard Management [DE Ramos, editor]. San Francisco, CA: University of California Division of Agriculture and Natural Resources.

45. Joseph. De Bello Judaic.lib.iii.cap 8.

46. Solà R \& Anglès F (2005) Historias, simbolismo y citas bíblicas de los frutos secos. In Frutos secos, salud y culturas mediterráneas [J Salas-Salvadó, E Ros and J Sabaté, editors]. Barcelona: Editorial Glosa.

47. Sturlusson S \& Byock JL (2005) The Prose Edda: Norse Mythology. London: Penguin Classics.

48. Kane M (1999) Heavens Unearthed in Nursery Rhymes and Fairy Tales. Altoona, PA: Golden Egg Books. 